\title{
SUTRIKUSIOS LOKOMOCIJOS VAIKŲ UGDYMO GALIMYBĖS BENDROJO LAVINIMO MOKYKLOSE: MOKYTOJŲ POŽIŪRIS
}

\author{
Genutė Gedviliené ${ }^{1}$, Zita Baužiene் $\dot{e}^{2}$ \\ Vytauto Didžiojo universitetas ${ }^{1}$, Kauno kolegija ${ }^{2}$, Kaunas, Lietuva
}

\begin{abstract}
Genutė Gedvilienė. Socialinių mokslų (edukologijos) daktarẻ. Vytauto Didžiojo universiteto Socialinių mokslų fakulteto Edukologijos katedros profesorè. Mokslinių tyrimų kryptis — mokymo ir mokymosi paradigmos, mokymosi grupėse interakcija: kognityvinių ir socialinių gebèjimų tyrimai.
\end{abstract}

\section{SANTRAUKA}

Tyrimo tikslas — atskleisti sutrikusios lokomocijos vaiku ugdymo galimybes ir kliütis bendrojo lavinimo mokykloje mokytoju požiūriu.

Naudoti šie tyrimo metodai: dokumentu analizè, anketinè apklausa. Lietuvos švietimo dokumentu analizè tyrimo metu pasitelkta siekiant ìvertinti sutrikusios lokomocijos vaiku situacija, išryškinti ir apibendrinti specialiajam ugdymui keliamus bendruosius reikalavimus. Europen Commision Eurostat, LR Statistikos departamento, LR Sveikatos ministerijos statistiniai duomenys leido atlikti sutrikusios lokomocijos vaiku populiacijos statistiniu duomenu analize. Kiekybinis tyrimas naudotas siekiant atskleisti pedagogu požiürį i mokyklu pasirengima ugdyti sutrikusios lokomocijos vaikus. Buvo tiriami mokytojai, bendravę su sutrikusios lokomocijos vaikais. Šio tyrimo metu taikytas anketinés apklausos metodas. Tyrimo duomenys analizuoti ir apibendrinti taikant „,SPSS 16 “ ir „,Microsoft Exsel “ programinius paketus. Ryšiu stiprumas ivvertintas Kendalo tau koreliacijos koeficientu (žymimas $\tau_{b}$ ) (Čekanavičius, Murauskienè, 2000; Vaitkevičius ir kt., 2006). Visi tyrimo etapais gauti duomenys apdoroti matematinès statistikos metodais naudoti aprašomosios statistikos ir dažniu procentais skaičiavimai. Anketinejje apklausoje dalyvavo Kauno miesto ir Kauno rajono bendrojo lavinimo mokyklu, gimnaziju, pradiniu mokyklu pedagogai $(n=82)$, bendrave arba turèje darbo patirties ugdydami sutrikusios lokomocijos vaikus. Didžiausia tiriamuju dalis - moterys $(93,90 \% ; n=77)$, vyrai sudare tik 6,1\% $(n=5)$. Atliktos pedagogu apklausos leido daryti išvadas apie mokyklu pasirengima ugdyti sutrikusios lokomocijos vaikus, informacijos, susijusios su ugdymo galimybemis, sklaida, palankiausia sutrikimu turinčiu vaiku ugdymo aplinka ir pedagogu pasirengimo svarbq. Informacija apie sutrikimu turinčiu vaiku ugdymo galimybes teikia Specialiojo ugdymo komisija, specialieji pedagogai, socialiniai pedagogai, sveikatos priežiūros darbuotojai, logopedai ir mokyklos administracija. Pedagogai patikimiausia laiko Specialiosios ugdymo komisijos teikiama informacija. Ugdant sutrikusios lokomocijos vaikus, reikšmingas pedagogu pasirengimas, kvalifikacija ir patirtis. Pedagogai teigia, kad mokyklos néra pritaikytos sutrikusios lokomocijos vaiku ugdymui bendrojo lavinimo klasèse: nepritaikyta fizinè mokykly aplinka, pedagogai nèra pasirengę tokiai veiklai.

Sio tyrimo rezultatai sutampa su J. Pivik ir kt. (2002), J. W. Santrock (2003), R. Rieser (2008) ir kt. gautaisiais, patvirtinančiais, kad neigalūs vaikai, stebèdami vaikus be lokomocijos sutrikimu ir sekdami ju pavyzdžiu, gali išmokti atitinkamo socialinio ir akademinio elgesio. Tačiau dauguma užsienio šaliu ir Lietuvos pedagogu aplinkos nepritaikyma bei saugumo negarantavima laiko pagrindinèmis integruoto ugdymo kliütimis.

Raktažodžiai: lokomocijos sutrikimas, ugdymo galimybès, kliūtys.

\section{IVADAS}

$\mathrm{V}$ isaverčiam žmogaus gyvenimui ypač didelès įtakos turi fizinè sveikata, psichologinė būklè, savarankiškumo laipsnis, socialiniai ryšiai su aplinka. Tobulejant medicininei technikai, sunkiu lokomocijos sutrikimų vaikams atsiranda galimybė gyventi visaverti gyvenima. Norint išvengti specialiujų ugdymo įstaigu ir siekiant sudėtingų lokomocijos sutrikimų vaikams sudaryti sąlygas gyventi namuose, galima orga- nizuoti jų mokymąsi kartu su bendraamžiais, kai kurias pamokas rengiant ne mokykloje, bet vaiko, turinčio sutrikimų, namuose.

Šiuo tyrimu, skirtu ugdymo psichosocialinei aplinkai mokykloje lokomocijos sutrikimo atveju, siekiama atsakyti i keliamą pagrindini problemini klausima: kokias ugdymosi galimybes turi sutrikusios lokomocijos vaikai? 
1 pav. Susirgimų, galinčių sukelti judèjimo sutrikimą, skaičius, tenkantis tūkstančiui $0-17 \mathrm{~m}$. vaikų

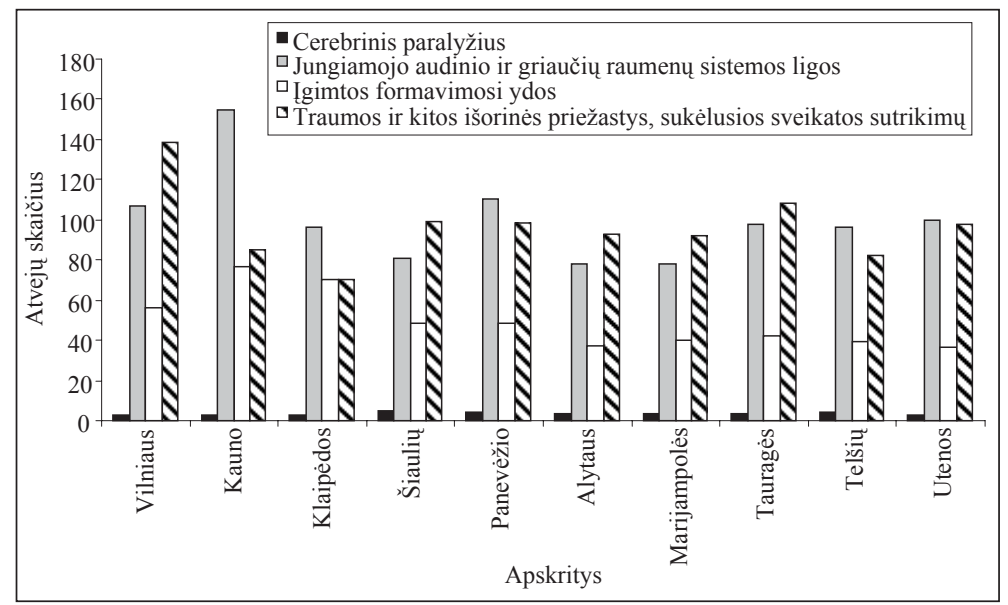

Tyrimo tikslas - atskleisti sutrikusios lokomocijos vaikų ugdymo galimybes ir kliūtis bendrojo lavinimo mokyklose mokytojų požiūriu.

Tyrimo objektas - sutrikusios lokomocijos vaikų ugdymo galimybès ir kliūtys bendrojo lavinimo mokyklose.

Smulkiosios ir bendrosios motorikos nepakankamumui būdingi judesių koordinacijos sutrikimai, negalèjimas arba ribotas gebejjimas atlikti judesius keičiant kūno padètị erdveje. Tokie sutrikimai vadinami lokomocijos sutrikimais. Jie skirstomi i laipsnius: nežymaus laipsnio, vidutinio laipsnio, žymaus laipsnio, labai žymaus laipsnio, visiško negalèjimo judèti (Ivoškuvienè, 1998; Bagdonas, 1999). Šiuos sutrikimus gali sukelti galvos arba nugaros smegenų pažeidimas, nes sutrikus normaliai inervacijai išsivysto paralyžius arba parezès.

Norint įvertinti sutrikusios lokomocijos vaiku populiacija, pasinaudota Europen Commision Eurostat duomenimis, kurie atskleidè, kad ligos ir sutrikimai, dẻl kurių nustatomas 16-24 metų paauglių / jaunuolių neigalumas, dažnai susiję su lokomocijos sutrikimais. $2002 \mathrm{~m}$. duomenys rodo, kad 16-24 metu asmenų susirgimai, susiję su reumatu, artritu bei kojų ir pėdu problemomis, dažniausiai nustatomi Vengrijoje (18\%) ir Austrijoje $(16,3 \%)$, rečiausiai - Airijoje $(7,8 \%)$, Švedijoje $(8,8 \%)$, Suomijoje (9\%). Dėl kojų ir pèdų problemų jaunuolių neigalumas dažniausiai nustatomas Austrijoje (15,4\%), rečiausiai - Norvegijoje $(4,1 \%)$. Judejjimo sutrikimus taip pat gali sukelti ivvairūs nugaros ir kaklo pakenkimai, artritas, reumatas, ivvairios nervu sistemos ligos, kai kurios lètinès ligos. Statistiniai duomenys rodo, kad dèl kaklo ir nugaros problemų neigaliaisiais dažniausiai pripažistami Danijos (15,5\%), Prancūzijos $(14,4 \%)$, o rečiausiai - Italijos $(5,5 \%)$ paaugliai / jaunuoliai. Dél nervų sistemos ligų daugiausia neigalumo atvejų nustatoma Vengrijoje $(32,2 \%)$, ma- žiausiai - Belgijoje (6,6\%). Ivairių lètinių ligu sukelti neigalumo atvejai dažniausiai užfiksuojami Olandijoje (22,5\%), rečiausiai - Danijoje (6,2\%). Nors negalima tvirtinti, kad 16-24 metu asmenys, neigaliaisiais pripažinti dèl minimų ligų ir turèję ar turintys nurodytu problemų, turi lokomocijos sutrikimų, svarbu tai, kad šie susirgimai dažniausiai sukelia lokomocijos sutrikimus.

Statistikos departamentas prie Lietuvos Respublikos vyriausybès pateikia informaciją apie susirgimus, dèl kurių 2006 m. 0-17 metų vaikai pripažinti neigaliais. Duomenys rodo, kad 2006 m. Lietuvoje berniukai $(n=2187)$ ir mergaitès $(n=1888)$ galèjo turèti lokomocijos problemų. Berniukai neigaliaisiais dažniausiai pripažistami dèl nervų sistemos ligu $(n=788)$, mergaitès — dèl igimtu formavimosi ydų, deformacijų ir chromosomų anomalijų $(\mathrm{n}=661)$. Didžiausias neigaliujų, galinčių turèti sutrikusią lokomociją, skaičius užfiksuotas 10-14 metų amžiaus grupèje, kurioje vyrauja nervų sistemos ligos. Daugumai šių vaiku pripažintas vidutinio sunkumo neigalumas $(\mathrm{n}=310$ berniukų ir $\mathrm{n}=220$ mergaičiu $)$, todèl tiketina, kad vaikai gali turèti vidutinio sunkumo lokomocijos sutrikimų. Statistiniai duomenys rodo, kad mieste užfiksuotas didesnis neigalumą turinčiu mergaičių ir berniukų skaičius $(n=1836)$ nei kaime $(n=1314)$. Tiek mieste, tiek kaime neigalumas dažniausiai sukeliamas igimtų formavimosi ydu, deformacijų ir chromosomų anomalijų.

Remiantis Lietuvos Respublikos Sveikatos ministerijos (2009) statistiniais duomenimis (1 pav.), rodančiais vaikų sergamumą Lietuvos apskrityse, galima pastebèti, kad $0-17$ metų vaikams Kauno apskrityje daugiausia nustatyta jungiamojo audinio ir griaučių raumenų sistemos ligų $(154,9)$, kurios gali sukelti lokomocijos sutrikima. Vilniaus apskrityje vaikai daugiausia $(138,7)$ patyrè sveikatos 
sutrikimų, sukeltų ivvairių traumų ir kitų išoriniu priežasčiu (pvz., apsinuodijimo).

Galima teigti, kad Lietuvoje dominuoja jungiamojo audinio ir griaučių raumenų sistemos ligos, traumu sukelti sveikatos sutrikimai ir igimtos formavimosi ydos, kurios gali sukelti lokomocijos sutrikimų.

Šiuo metu integruoto vaiku, turinčiu ivvairių raidos sutrikimu, ugdymo problema sulaukia didelio pasaulio edukologų dèmesio, kurie savo tyrimais aptaria lètinių, ortopedinių ir neuroraumeninių ligu poveiki paauglių santykiams su bendraamžiais, analizuoja galimybes sukurti palankią ugdymo aplinką, skirtą sutrikusios lokomocijos vaikams (sergantiems cerebriniu paralyžiumi), inkliuzinio ugdymo sampratą kaip galimybę, leidžiančią atsižvelgti ị visų vaikų poreikius, visuomenès požiūrio kaita neigaliuju atžvilgiu ir pan.

Australijoje, Kanadoje, Honkonge ir Singapūre (Loreman et al., 2007) atliktas tyrimas atskleidè mokytoju praktikantų, planuojančių dirbti ikimokyklinio ugdymo pradinèse ir vidurinès mokyklos klasèse, pasirengimą inkliuzinio ugdymo praktikai. Tyrimo rezultatai parodè, kad mokytojai praktikantai palankiai žiūri $\mathfrak{i}$ asmenis, turinčius mokymosi ar fiziniu poreikiu, ir patvirtino, kad glaudus kontaktas su neigaliaisiais ugdo teigiamą asmenu be negalios požiūrị i bendradarbiavimo galimybes (Carroll et al., 2003). Šalyse, kuriose inkliuzinis ugdymas vykdomas ilgesni laiko tarpą, požiūris i fizinę ar kognityvinę negalią turinčių asmenu mokymąsi kartu su kitais asmenimis, neturinčiais negalios, palankus (Loreman et al., 2005).

J. McComas ir kt. (1998) Otavos universitete atliko tyrima, kurio tikslas - padidinti lokomocijos sutrikimų turinčių vaikų mobilumą, virtualios aplinkos pagalba sukuriant realios aplinkos situacijas (pvz., prekybos centro, sankryžos ir pan.). Naudodamiesi iqvairiomis apsaugos priemonèmis (pvz., šalmais), vaikai mokosi valdyti elektrinius vežimèlius. Virtuali aplinka, imituojanti realią tikrovę, leidžia išvengti sužalojimų ugdant neigaliu vaiku gebejjimus judèti, o šie gebejjimai padeda isitraukti į realų gyvenimą.

Užsienio šalių patirtis rodo, kad nepaisant palankaus požiūrio i̇ sutrikimų turinčių vaikų udymą kartu su kitais vaikais daug problemų kelia fizinè aplinka, nepritaikyta neigaliesiems (Pivik et al., 2002; Eriksson, Grandlund, 2004; Schenker et al., 2005). Šių mokslininkų tyrimų rezultatai atskleidè, kad vaikai, turintys lokomocijos sutrikimų, rečiau dalyvauja daugelyje veiklos sričiu nei vaikai iš bendrosios populiacijos: jie negali kartu su bendraamžiais žaisti judriuju žaidimų, nesijaučia saugūs, neretai turi bandyti išvengti skaudaus bendraamžiu elgesio ir patyčių. Pastebèta, kad vaikų, negalinčių lygiaverčiai dalyvauti bendroje veikloje, nepakankamai išlavinti socialiniai gebejjimai. Apskritai, laikantis tradicinių mokymo programų ir metodų, sumažejja sutrikusios lokomocijos vaiku galimybe mokytis bendrojo lavinimo mokykloje. Dar viena kliūtis, trukdanti vaiku integracijai, - mokytojų nepasirengimas dirbti su skirtingu poreikių vaikais (Pivik et al., 2002; Burstein et al., 2004).

Užsienio šalyse sukaupta sutrikusios lokomocijos vaikų ugdymo patirtis turi itakos Lietuvos švietimo politikai, kuri grindžiama Vakarų Europoje priimtomis humaniškumo, demokratiškumo, normalizacijos ir integracijos idejomis. Remiantis (Avramidis, Norwich, 2002; Carroll et al., 2003; Loreman et al., 2005) užsienio mokslininkų atliktais tyrimais galima daryti išvadą, kad rengiant mokytojus reikètu sudaryti galimybę atlikti praktiką inkliuzinejje aplinkoje. Taip jauni mokytojai galètu igyti darbo patirties ir pasitikejjimo savo jègomis. Kaip teigia M. Loreman ir kt. (2005), sėkminga inkliuzinio ugdymo patirtis suteikia daugiau pasitikejjimo, ir tai skatina palankesni požiūri i inkliuzini ugdymą.

Nepriklausomybės metais paskelbta daugiau nei 20 specialuji ugdymą reglamentuojančių dokumentų, tarp jų LR Konstitucija (1996), LR Švietimo istatymas (1991, nauja redakcija - 2003), Specialiojo ugdymo istatymas (1998) ir kt. Tarptautiniuose ir Lietuvos švietimo sistemą reglamentuojančiuose dokumentuose pabrèžiama, kad specialusis ugdymas negali plètotis izoliuotai, jis turètų būti visuotinio švietimo strategijos ir naujos socialinès-ekonominès politikos dalis, skatinanti keisti tradicinę mokyklą bei visą švietimo sistemą. Šie pokyčiai tiesiogiai susiję su mokinių, turinčių specialiujų ugdymo poreikių, aprūpinimu specialiosiomis mokymo priemonėmis, ugdymui skirta kompensacine technika ir informacinemis technologijomis, specialiosios pedagoginès ir psichologinès pagalbos garantavimu.

Minètuose dokumentuose itvirtinama aiški nuostata - ivairių raidos sutrikimų, taip pat ir sutrikusios lokomocijos mokinius ugdyti arčiausiai namų esančiose ugdymo įstaigose, bendrojo lavinimo mokykloje kartu su jų bendraamžiais. Todèl šiuo metu sutrikusios raidos vaiku specialiosiose mokyklose mažèja, o bendrojo lavinimo mokyklose daugèja. Tiesa, beveik nesikeičia sutrikusios lokomocijos vaiku situacija. 


\section{TYRIMO METODIKA}

Literatūros analizès metodas naudotas norint atskleisti sutrikusios lokomocijos vaikų tyrimu tarptautinę patirti. Europen Commision Eurostat, LR Statistikos departamento, LR Sveikatos ministerijos statistiniai duomenys leido atlikti sutrikusios lokomocijos vaiku populiacijos statistiniu duomenu analizę.

Anketinès apklausos metodas. Norint išsiaiškinti pagrindines sutrikusios lokomocijos vaiku ugdymo bendrojo lavinimo mokykloje galimybes, kliūtis ir palankiausias socialinių gebejjimų ugdymo sąlygas, parengtos anoniminès struktūruotos anketos, sudarytos iš uždarojo tipo klausimu. Atliekant tyrimą susidurta su imties apibrèžties problema. Siekiant reprezentatyvumo svarbu nustatyti tinkamą apklausiamų respondentų skaičių ir ju parinkimo būdus, tačiau Lietuvoje nèra pateikiama tiksliu statistiniu duomenu apie sutrikusios lokomocijos vaikų skaičių.

Imčiai sudaryti pasirinkta netikimybinè atranka, kadangi, kaip minèta, nèra žinomas tikslus sutrikusios lokomocijos vaiku pasiskirstymas populiacijoje, todèl kiekvieno nario įtraukimo i tiriamaja grupę tikimybè negali būti apibrèžta (Charles, 1999; Kardelis, 2005). Anketineje apklausoje dalyvavo Kauno miesto ir Kauno rajono bendrojo lavinimo mokyklų, gimnaziju, pradiniu mokyklų pedagogai $(n=82)$, bendravę arba turejję darbo patirties ugdydami sutrikusios lokomocijos vaikus. Tyrimo metu mokytojams buvo išdalyta 100 anketu, iš jų grąžinta $82(82 \%)$. Didžiausia tiriamuju dalis - moterys $(93,90 \% ; \mathrm{n}=77)$, vyrai sudare tik $6,1 \%(\mathrm{n}=5)$.

Statistikos metodai. Tyrimo duomenys analizuoti ir apibendrinti taikant SPSS 16 ir Microsoft Exsel programinius paketus. Ryšiu stiprumas ivertintas Kendalo tau koreliacijos koeficientu (žymimas $\tau_{b}$ ) (Čekanavičius, Murauskas, 2000; Vaitkevičius ir kt., 2006). Visais tyrimo etapais gauti duomenys apdoroti matematinès statistikos metodais - naudoti aprašomosios statistikos ir dažnių procentais skaičiavimai.

\section{REZULTATAI}

Empirinis kiekybinis tyrimas padèjo atskleisti šiuos rezultatus. Atsakydami i klausimą, kas suteikia informacijos apie sutrikusios lokomocijos vaiku mokymosi galimybes, apie $40 \%$ respondentu teigia, kad jiems informaciją ir rekomendacijas teikia Specialioji ugdymo komisija, tačiau 11\% mokytojų teigia niekada negaunantys reikalingos informacijos iš Specialiojo ugdymo komisijos. Apibendrinus respondentų atsakymus galima daryti išvadą, kad Specialiojo ugdymo komisija pakankamai informuoja apie sutrikusios lokomocijos vaikų mokymosi galimybes. Gautas reišmingas statistinis skirtumas $\left(\chi^{2}=17,0 ; \mathrm{f}=3 ; \mathrm{p}<0,0001\right)$ parodo, kad nuomonè yra nevienareiškmè. $20 \%$ apklaustų mokytojų visada ir apie $20 \%$ dažniausiai arba kartais tenkina iš mokyklos administracijos gaunama informacija. Pasak $60 \%$ respondentuc, mokyklos administracija jiems visiškai neteikia informacijos. Apibendrinant apklaustujų atsakymus galima teigti, kad mokyklos administracijos teikiama informacija ne visada tenkina minètu respondentu poreikius, ir tai patvirtina reikšmingas statistinis skirtumas $\left(\chi^{2}=25,9 ; \mathrm{f}=3 ; \mathrm{p}<0,001\right)$.

I klausima, ar specialistų (socialinių pedagogų, specialiuju pedagogų, logopedų, sveikatos priežiūros darbuotojų) teikiama informacija apie sutrikusios lokomocijos vaikų mokymosi galimybes yra veiksminga, išsami, respondentų atsakymai labai ìvairūs (1 lent.).

Socialinio pedagogo teikiama informacija visada tenkina tik $13 \%$ respondentų, tačiau $37 \%$ apklaustujų teigia, kad tokia informacija juos tenkina dažniausiai. Dauguma respondentų nurodè, kad „socialinis pedagogas rūpinasi vaikais iš asocialiu šeimu“", „socialinis pedagogas tik pildo popierius apie įvairias šeimas“, „socialinis pedagogas domisi tik padidinto rizikos faktoriaus vaikais". Rezultatu skirtingumą patvirtina gautas statistiškai reikšmingas skirtumas $\left(\chi^{2}=14,987 ; \mathrm{f}=3 ; \mathrm{p}<0,002\right)$.

Specialiojo pedagogo gaunamą informaciją ir rekomendacijas vertina teigiamai (apie 21\% visada ir apie $36 \%$ - dažniausiai).

\begin{tabular}{|c|c|c|c|c|c|c|}
\hline \multirow{5}{*}{$\begin{array}{l}1 \text { lentelè. Mokytojų vertini- } \\
\text { mas specialistų teikiamos in- } \\
\text { formacijos apie sutrikusios } \\
\text { lokomocijos vaikų mokymosi } \\
\text { galimybes }(\%)\end{array}$} & $\begin{array}{ll}\text { Specialistai } & \text { Atsakymai } \\
\end{array}$ & Visada & Dažniausiai & Kartais & Nesikreipiau & $\begin{array}{c}\text { Rekomendacijos } \\
\text { neteikiamos }\end{array}$ \\
\hline & Socialinis pedagogas & 13 & 37 & 27 & 17 & 6 \\
\hline & Specialusis pedagogas & 21 & 36 & 13 & 13 & 17 \\
\hline & Logopedas & 24 & 38 & 11 & 15 & 12 \\
\hline & Sveikatos priežiūros darbuotojas & 13 & 37 & 27 & 17 & 6 \\
\hline
\end{tabular}




\begin{tabular}{|c|c|c|}
\hline $\begin{array}{ll} & \text { Atsakymai } \\
\text { Kliūtys } & \\
\end{array}$ & Taip (M) & $\mathrm{Ne}(\mathrm{M})$ \\
\hline Nepritaikytos mokyklos & 95 & 4 \\
\hline Neįrengti keltuvai & 91 & 6 \\
\hline Neįrengti įvažiavimai & 88 & 10 \\
\hline Nepritaikyti tualetai & 94 & 6 \\
\hline Nepritaikyta valgykla & 75 & 19 \\
\hline Negarantuota medicininè pagalba & 80 & 14 \\
\hline
\end{tabular}

2 lentelè. Mokyklos fizinès aplinkos vertinimas (mokytojų duomenys - M, \%)

\begin{tabular}{|c|c|c|c|c|}
\hline \multirow{2}{*}{ Nr. } & \multirow[b]{2}{*}{ Mokytojų požiūris } & Taip & $\mathrm{Ne}$ & Nežinau \\
\hline & & M & $\mathbf{M}$ & $\mathbf{M}$ \\
\hline 1. & $\begin{array}{l}\text { Mokytojai nepasirengę dirbti kartu su sveikais } \\
\text { ir sutrikusios lokomocijos vaikais }\end{array}$ & 50 & 24 & 26 \\
\hline 2. & Nenori mokytojai & 52 & 32 & 16 \\
\hline 3. & Nenori sveikų vaikų tėvai & 10 & 20 & 70 \\
\hline 4. & Nenori sutrikusios lokomocijos vaikų tėvai & 9 & 28 & 63 \\
\hline 5. & $\begin{array}{l}\text { Mokyklų bendruomenė nepasiruošusi priimti } \\
\text { sutrikusios lokomocijos vaikų }\end{array}$ & 49 & 23 & 28 \\
\hline 6. & Negarantuota psichologinè pagalba & 57 & 28 & 15 \\
\hline
\end{tabular}

3 lentelè. Mokytojų požiūris i galimybę sutrikusios lokomocijos vaikus ugdyti bendrojo lavinimo mokykloje (\%)

Informaciją, kurią teikia logopedas, respondentai vertino analogiškai kaip ir kitų specialistų. Pasak 24\% mokytoju, logopedas teikia informacija visada, 38\% respondentų nurodo, kad jiems informacija suteikiama dažniausiai.

Didesnè dalis respondentų (13\% — visada ir 37\% - dažniausiai) teigiamai vertina sveikatos priežiūros darbuotojo teikiamą informaciją ir rekomendacijas, tačiau kai kurie respondentai tvirtina, kad mokykloje nèra sveikatos priežiūros darbuotojo.

95\% respondentų tvirtina, kad mokyklos yra nepakankamai pasiruošusios ir pritaikytos sutrikusios lokomocijos vaikų ugdymui (2 lent.). Respondentai teigia, kad mokyklų steigejjai negarantuoja specialiujų poreikių turinčių asmenų iki 21 metų, nepajėgiančių atvykti i bendrojo lavinimo mokyklas (negalinčių savarankiškai vaikščioti, dèl didelių sutrikimų nesaugiai besijaučiančių gatvèje), atvežimo (statistinis reikšmingumas nepastebètas $p>0,7854)$. Nors šią paslaugą teikti ipareigoja LR Švietimo įstatymo 36 straipsnis (Valstybès žinios, 1998, Nr. 67), dauguma sutrikusios lokomocijos vaikų negali atvykti ị mokyklą ir laisvai judeti mokyklos patalpose, todèl yra ugdomi namuose.

$50 \%$ respondentu pritaria, kad sutrikusios lokomocijos vaikai gali mokytis kartu su sveikai- siais, apie $40 \%$ apklaustujų teigia, kad įmanoma tik kai kuriais atvejais.

Pusè apklaustų mokytoju mano, kad sutrikusios lokomocijos vaikai gali dalyvauti popamokineje veikloje, 25\% teigia, kad mokytojai to nenorintys. Respondentai nurode priežastis, kurios trukdo dalyvauti popamokinejje veikloje, būtent: neįmanoma garantuoti saugumo $(n=60$ mokytojų); bijoma sveikų vaikų konkurencijos; „gali nusibosti“; ,jie negražiai atrodo“ ir pan.

$50 \%$ apklaustujų nėra pasirengę dirbti grupèse, kuriose būtu sutrikusios lokomocijos vaikų (3 lent.). Apie 52\% respondentu mano, kad jie apskritai nenori dirbti tokios sudèties moksleiviu grupèse. 90\% mokytojų nežino, ar tẻvai, kuriu vaikai neturi sutrikimų, leistu juos mokytis kartu su sutrikimų turinčiais vaikais. Tokius skirtingus respondentų rezultatus patvirtina gautas statistiškai reikšmingas skirtumas $\left(\chi^{2}=8,00 ; f=2\right.$; $\mathrm{p}<0,002)$.

$10 \%$ respondentų mano: tèvai nenorètų, kad jų vaikai mokytųsi kartu su neigaliais vaikais. $63 \%$ apklaustujų nežino, ar tėvai, turintys sutrikusios lokomocijos vaikų, sutiktų, kad jų vaikai mokytųsi kartu su vaikais be sutrikimų. Tai patvirtina gautas reikšmingas skirtumas $\left(\chi^{2}=12,66 ; f=2\right.$; 
4 lentelè. Mokytojų požiūrio į sutrikusios lokomocijos vaikus kaita (\%)

\begin{tabular}{|c|l|c|c|c|}
\hline Nr. & Atsakymai & Taip & Ne & Nežinau \\
\hline 1. & Mokytojų požiūris & 88 & 8 & 4 \\
\hline 2. & Geriau juos suprantate & 100 & 0 & 0 \\
\hline 3. & Norite jiems padèti & 98 & 0 & 2 \\
\hline 4. & Daugiau rūpinatès & 87 & 9 & 4 \\
\hline 5. & Labiau jais pasitikite & 88 & 8 & 4 \\
\hline 6. & Jums labiau rūpi jų problemos & 88 & 6 & 6 \\
\hline 7. & Drąsiau juos ginate, jei reikia & 90 & 4 & 6 \\
\hline 8. & Jūs nepastebite jų negalios & 65 & 27 & 8 \\
\hline 9. & Susidraugavote & 85 & 0 & 15 \\
\hline 10. & Bendravimas su jais jus vargina & 9 & 82 & 9 \\
\hline 11. & Jie kelia jums nepatogumu & 11 & 78 & 11 \\
\hline 12. & Atsirado nepasitikèjimas jais & 8 & 6 & 86 \\
\hline 13. & Atsirado nesaugumo jausmas & 82 & 8 \\
\hline
\end{tabular}

$\mathrm{p}<0,002)$. Tokie rezultatai parodo bendruomenès požiūrị i neigaliuosius.

Tyrimo rezultatai atskleide, kad mokytojams, bendravusiems su sutrikusios lokomocijos vaikais, būdinga požiūrio į šiuos vaikus kaita. Šios kaitos požymiai pateikti 4 lenteleje. Pastebèti pozityvaus požiūrio požymiai: ,jei reikia, mokytojai drąsiau gina sutrikimų turinčius vaikus“, „mokytojams pradeda labiau rūpeti sutrikimu turinčių vaiku problemos“, „mokytojai susidraugauja su sutrikusios lokomocijos vaikais ir nepastebi jų negalios". Taip pat išryškejo respondentų negatyvus požiūris, kuris išreikštas teiginiais „atsirado nesaugumo jausmas“, „,bendravimas su jais vargina“, „atsirado nepasitikèjimas savimi" ir kt.

Šio tyrimo rezultatai patvirtina E. Avramidi, B. Norwich (2000), R. Rieser (2008) ir kt. išvadas: pedagogu bendravimas su sutrikusios lokomocijos vaikais praturtina abipusiškai. Toks santykis ugdo pedagogo socialinius gebėjimus.

Tyrimo rezultatai parodè, kad sutrikusios lokomocijos vaikai igyja vaiku be sutrikimu pasitikejjimą, o pastarieji išmoksta bendrauti $\left(\tau_{b} \approx 0,957 ; \mathrm{p}<0,01\right)$; bendravimo metu vyrauja teigiamos emocijos $\left(\tau_{b} \approx 0,739 ; \mathrm{p}<0,01\right)$; vaikai be sutrikimu tampa jautresni sutrikusios lokomocijos vaiku problemoms ir su sutrikimu susijusiems sunkumams ( $\left.\tau_{b} \approx 0,704 ; \mathrm{p}<0,01\right)$; vaikai be sutrikimu pradeda geriau suprasti kitus ir išmoksta išklausyti ( $\left.\tau_{b} \approx 0,732 ; \mathrm{p}<0,01\right)$, žino, kada ir kaip suteikti pagalbą, kitaip tariant, tampa paslaugesni $\left(\tau_{b} \approx 0,732 ; \mathrm{p}<0,01\right)$. Šie rezultatai patvirtina požiūrio kaitą ì neigaliuosius.

Respondentai, tureję kontaktų su sutrikusios lokomocijos vaikais, daugeliu atveju pakeitè savo požiūrị i neigaliuosius (neigalieji, stebèdami vaikus be judejjimo sutrikimų ir sekdami jų pavyzdžiu, gali išmokti atitinkamo socialinio ir akademinio elgesio - tai mineta ir J. W. Santrock (2003), R. Rieser (2008) tyrimuose)).

$62 \%$ respondentu teigia, kad su sutrikusios lokomocijos vaikais bendrauja kaip su sveikaisiais ( 2 pav.). Toks rezultatas patvirtina daugelio respondentu požiūrị.

Apibendrinant tyrimo rezultatus galima teigti, kad visuomenè nepakankamai pažįsta sutrikusios lokomocijos vaikus. Todèl pastarujų atžvilgiu vyrauja neigiamos nuostatos. Visgi tyrimo rezultatai patvirtino, kad sudarius galimybes bendrauti, kliūtys sutrikusios lokomocijos vaikų atžvilgiu darosi mažiau ryškios.

Respondentų nuomonė apie sutrikusios lokomocijos vaikų saugumą mokykloje dažniausiai neigiama. $85 \%$ apklaustuju, teigia, kad jie negali garantuoti vaiku saugumo. Šio tyrimo rezultatai sutampa su J. Pivik ir kt. (2002), A. Galkienès (2003) ir kt. gautaisiais, rodančiais, kad dauguma užsienio šalių ir Lietuvos tèvų saugumo negarantavimą laiko viena iš integruoto ugdymo kliūčių. Apie 50\% mokytojų mano, kad sutrikusios loko- 


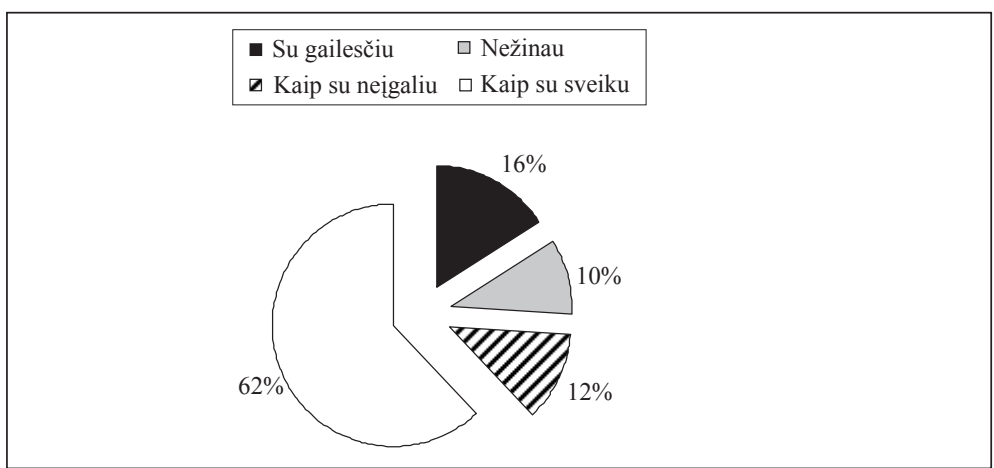

2 pav. Mokytojų bendravimo pobūdis su sutrikusios lokomocijos vaiku

mocijos vaikai mokytųsi kartu su sveikaisiais, vadinasi, jie tiki šių vaikų galimybėmis.

\section{REZULTATUQ APTARIMAS}

Analizuojant literatūrą aptikti tyrimai, atlikti tarptautiniu mastu šiose šalyse: Australijoje, Kanadoje, Honkonge ir Singapūre (Loreman et al., 2007). Jie parode, kad mokytojai praktikantai palankiai žiūri į asmenis, turinčius mokymosi ar fizinių poreikiu, ir patvirtino, kad glaudus kontaktas su neigaliaisiais ugdo teigiamą asmenų be negalios požiūri i bendradarbiavimo galimybes (Carroll et al., 2003). Šalyse, kuriose inkliuzinis ugdymas vykdomas ilgesni laiko tarpa, požiūris i fizinès ar kognityvinès negalios asmenų mokymąsi kartu su kitais, neturinčiais negalios, palankus (Loreman et al., 2005).

J. McComas ir kt. (1998) Otavos universitete atliko tyrimą, kurio tikslas - padidinti sutrikusios lokomocijos vaiku mobilumą, virtualios aplinkos pagalba sukuriant realios aplinkos situacijas. Naudodamiesi iqvairiomis apsaugos priemonemis, vaikai mokosi valdyti elektrinius vežimèlius. Virtuali aplinka, imituojanti realią tikrovę, leidžia išvengti sužalojimų ugdant neigaliu vaikų gebèjimus judèti, o šie gebejimai padeda issitraukti i realų gyvenima.

Užsienio šalių patirtis rodo, kad nepaisant palankaus požiūrio į sutrikimų turinčių vaikų ugdymą kartu su kitais daug problemu kelia fizinè aplinka, nepritaikyta neigaliesiems (Pivik et al., 2002; Eriksson, Granlund, 2004; Schenker et al., 2005). Šių mokslininkų tyrimų rezultatai atskleidè, kad sutrikusios lokomocijos vaikai rečiau dalyvauja daugelyje veiklos sričių nei vaikai iš bendrosios populiacijos. Pastebėta, kad vaikų, negalinčiu lygiaverčiai dalyvauti bendroje veikloje, nepakankamai išlavinti socialiniai gebejjimai. Apskritai, laikantis tradicinių mokymo programų ir mokymo metodu, sumažeja sutrikusios lokomocijos vaiku galimybès mokytis bendrojo lavinimo mokykloje.
Dar viena kliūtis, trukdanti vaikų integracijai, mokytojų nepasirengimas dirbti su skirtingų poreikių vaikais (Pivik et al., 2002; Burstein et al., 2004;).

Mūsų tyrimo rezultatai atskleidè, kad sutrikusios lokomocijos vaiku mokymosi galimybiu klausimas yra nepakankamai išspręstas. Pastaruoju metu dominuoja kliūtys, trukdančios sutrikusios lokomocijos vaikams mokytis kartu su bendraamžiais, ir jos yra panašios i minètu užsienio mokslininkų aprašytas — nepritaikyta fizinè aplinka, nepakankamas pedagogu pasirengimas dirbti klasėse, kuriose mokosi vaikai, turintys ivairių sutrikimu.

\section{IŠVADOS}

Ivairių dokumentų (Europos Sajungos sutarties (Mastriko sutarties), Jungtinių Tautų Vaiko teisių konvencijos, Lietuvos Respublikos Švietimo koncepcijos, Specialiojo ugdymo metmenų, Lietuvos Respublikos Konstitucijos, Lietuvos Respublikos Invalidu socialinès integracijos istatymo, Lietuvos Respublikos Švietimo istatymo, Specialiojo ugdymo įstatymo, Nacionalinès žmonių su negalia socialinès integracijos 2003-2012 m. programos) analizė atskleidè, kad visuomenè yra skatinama pripažinti asmenu skirtumus ir kurti sąlygas, leidžiančias neigaliems vaikams mokytis bendrojo lavinimo mokyklose.

Kiekybinis tyrimas padejjo atskleisti mokyklų pasirengimą ugdyti sutrikusios lokomocijos vaikus, informacijos, susijusios su ugdymo galimybėmis, sklaidą, palankiausią sutrikimu turinčių vaikų ugdymo aplinką ir pedagogu pasirengimo svarbą.

- Informaciją apie sutrikimų turinčių vaikų ugdymo galimybes teikia Specialiojo ugdymo komisija, specialieji pedagogai, socialiniai pedagogai, sveikatos priežiūros darbuotojai, logopedai ir mokyklos admi- 
nistracijos. Pedagogai patikimiausia laiko Specialiosios ugdymo komisijos teikiamą informacija.

- Ugdant sutrikusios lokomocijos vaikus, reikšmingas pedagogu pasirengimas, kvalifikacija ir patirtis. Mokytojai teigia, kad viena iš kliūčių ugdyti sutrikusios lokomo- cijos vaikus bendrojo lavinimo mokykloje — baimé dèl vaiko saugumo. Pedagogai teigia, kad mokyklos nèra pritaikytos sutrikusios lokomocijos vaiku ugdymui bendrojo lavinimo klasèse: nepritaikyta fizinè mokyklų aplinka, pedagogai nėra pasirengę tokiai veiklai.

\section{LITERATŪRA}

Avramidis, E., Norwich, B. (2002). Teachers' attiudes towards integration / inclusion: A rewiew of the literature. European Journal of Secial Needs Education, 172, 129-147.

Bagdonas, A. (red.). (1999). Tarptautine ydu, veiklu ir dalyvumo klasifikacija: neigalumo ir funkcionavimo matmenu vadovélio BETA-1 apmatai. Vilnius: PSICHËJA.

Burstein, N., Sears, S., Wilcoxen, A., Cabello, B., Spagna, M. (2004). Moving toward inclusive practices. Remedial and Special Education, 25, 104-116.

Carroll, A., Forlin, C., Jobling, A. (2003). The impact of teacher training in special education on the attitudes of Australian preservice general educators towards people with disabilities. Teacher Education Quarterly, 303, 65-79.

Charles, C. M. Z. (1999). Pedagoginio tyrimo ivadas. Vilnius: Alma littera.

Čekanavičius, V., Murauskas, G. (2000). Statistika ir jos taikymai I. Vilnius: TEV.

Eriksson, L., Granlund, M. (2004). Perceived participation: A comparison of students with disabilities and students without disabilities. Scandinavian Journal of Disability Research, 6, 206-224.

European Commision: Eurostat. (2009). [Žiūrèta 200912 10]. Prieiga internetu:

http://epp.eurostat.ec.europa.eu/portal/page/portal/health/ public_health/main_tables

Galkienè, A. (2003). Pedagogine sqveika integruoto ugdymo salygomis. Šiauliai: Šiaulių universiteto leidykla.

Ivoškuvienè, R. (1998). Vaiku fiziniai ir judejjimo sutrikimai. J. Ambrukaitis (sud.), Specialiuju poreikiu vaikai. Šiauliai: Šiaulių universiteto leidykla.

Kardelis, K. (2005). Moksliniu tyrimu metodologija ir metodai. Šiauliai: Šiauliu universiteto leidykla.

Lietuvos Respublika. Konstitucija. (1996). Vilnius: Lietuvos informacijos centras prie teisingumo ministerijos.

Lietuvos Respublikos specialiojo ugdymo istatymas Nr. VIII-969. (1998). [Žiūrèta 200605 14]. Prieiga internetu: http://www.smm.lt/ti/docs/istatymai/viii-969.htm
Lietuvos Respublikos Sveikatos apsaugos ministerija, Lietuvos Sveikatos informacijos centras. (2009). Lietuvos gyventoju sergamumas apskrityse ir savivaldybèse [žiūrèta 200912 15]. Prieiga internetu: http://www.lsic.lt

Lietuvos Respublikos švietimo istatymo nauja redakcija Nr. IX-1630. (2003). Valstybès žinios, 63, 2853.

Loreman, T., Deppler, J., Harvey, D. (2005). Inclusive Education: A Practical Guide to Supporting Diversity in the Classroom. Crows Nest, NSW: Allen, Unvin.

Loreman, T., Forlin, Ch., Sharma, U. (2007). An International Comparison of Pre-service Teacher Attitudes towards Inclusive Education. Disability Studies Quarterly, 27 (4) [žiūrèta 200905 13]. Prieiga internetu: http://www. dsq-sds.org/article/view/53/53

McComas, J., Pivik, J., Laflamme, M. (1998). Curent uses of virtual reality for children with disabilities. G. Riva, B. K. Wiederhold, E. Molinari (Eds.), Virtual Environments in Clinical Psychology and Neuroscience. Amsterdam: Ios Press.

Pivik, J., McComas, J., LaFlamme, M. (2002). Barriers and facilitators to inclusive education. Exceptional Chidren, 69, 97-107.

Rieser, R. (2008). Implementing Inclusive Education: A Commonwealth Guide to Implementing Article 24 of the UN Convention on the Rights of People with Disabilities. London: Commonwealth Secretariat.

Santrock, J. W. (2003). Children. Boston: McGraw-Hill.

Schenker, R., Coster, W., Parush, S. (2005). Participation and activity performance of students with cerebral palsy within the school enviroment. Journal of Disability and Rehabilitation, 27 (10), 539-552.

Statistikos departmentas prie LRV. (2006). Neigalumo ir darbingumo nustatymo tarnybos duomenys [žiūrèta 200912 10]. Prieiga internetu: www.stat.gov.lt

Vaitkevičius, R., Saudargienė, A. (2006). Statistika su SPSS psichologiniuose tyrimuose. Kaunas: VDU leidykla. 


\title{
EDUCATION OPPORTUNITIES FOR CHILDREN WITH LOCOMOTION DISORDERS IN COMPREHENSIVE SCHOOLS: TEACHERS' APPROACH
}

\author{
Genutė Gedviliené $\dot{1}^{1}$ Zita Baužiené $\dot{e}^{2}$ \\ Vytautas Magnus University ${ }^{1}$, Kaunas College ${ }^{2}$, Kaunas, Lietuva
}

\begin{abstract}
The aim of article was to determine education opportunities and barriers for children with locomotion disorders in secondary schools from the teachers' approach.

Scientific research methods used in the survey were as follows: document analysis and questionnaire survey. The analysis of Lithuanian educational documents was used in order to estimate the situation of children who had locomotion disorders and to highlight and summarize general requisitions for special education. Statistical analysis of the population of children with locomotion disorders was carried out using the data of the European Commission Eurostat, Department of Statistics of Lithuania and Ministry of Health of the Republic of Lithuania. Quantitative research was performed in order to evaluate the approach of teachers towards the readiness of schools to educate children with locomotion disorders. The survey involved teachers who communicated with children with locomotion disorders. For this research a questionnaire survey was used. The research data were analyzed and summarized using the software package SPSS 16 and Microsoft Excel. The correlations were evaluated using Kendall's tau (noted $\tau_{b}$ ) correlation coefficient (Čekanavičius et al., 2000; Vaitkevičius et al., 2006). All data were processed by statistical methods: descriptive statistics and calculation of frequency percentage.

The survey involved teachers from Kaunas city and Kaunas district secondary schools, gymnasiums, primary schools $(\mathrm{n}=82)$ who communicated or had work experience in training children with locomotion disorders. The largest part of the research respondents were females $-93.90 \%(n=77)$ and only $6.1 \%$ $(\mathrm{n}=5)$ males.

Interviewing the teachers led to conclusions on the preparation of schools to provide education to children with locomotion disorders, data on training possibilities, dissemination, most favourable training environment for children with disorders and importance of training teachers.

Enquiries on training opportunities for disordered children are addressed by the Commission of Special Training, special teachers, social teachers, healthcare personnel, speech therapist and school administration. Teachers consider the information provided by the Commission of Special Training to be most reliable. For training children with locomotion disorders, teachers' qualification, experience and preparation are important. Teachers claim that schools are not adaptable to teaching children with locomotion disorders within secondary education schools: unequipped physical environment of schools, insufficient qualification of teachers.

This research results coincide with the results of the research performed by J. Pivik (2002), J. W. Santrock (2003), R. Rieser (2008) and etc. which prove that children with disabilities can learn some social and academic behaviour while watching children without disabilities. However, most foreign and Lithuanian teachers consider the lack of equipped physical environment and safety of children in schools to be the most important barriers of inclusive teaching.
\end{abstract}

Keywords: locomotion disorders, education, opportunities, safety.

Gauta 2010 m. rugsėjo $21 \mathrm{~d}$.

Received on September 21, 2010

Priimta 2010 m. lapkričio $18 \mathrm{~d}$.

Accepted on November 18, 2010

Genutè Gedvilienè

Vytauto Didžiojo universitetas

(Vytautas Magnus University)

K. Donelaičio g. 52-310, LT-44244 Kaunas

Lietuva (Lithuania)

Tel +37061138100

E-mail g.gedviliene@smf.vdu.lt 